\title{
Students' Perceptions about the Implementation of Peer-Assisted Reflection Learning in Multivariable Calculus Lectures
}

Received 03-05-2021:; Revised 12-06-2021:; Accepted:14-06-2021

\section{Isra Nurmai Yenti *)}

Universitas Pendidikan Indonesia

Institut Agama Islam Negeri Batusangkar

Email:

isra.nurmai.yenti@student.upi.edu; isranurmaiyenti@iainbatusangkar.ac.id

\section{Yaya S. Kusumah}

Universitas Pendidikan Indonesia

E-mail: yayaskusumah@yahoo.com

\section{Jarnawi Afghani Dahlan}

Universitas Pendidikan Indonesia

E-mail:jarnawi@upi.edu

*) Corresponding Author

\begin{abstract}
A large class can be a problem source in learning Calculus. Peer-Assisted Reflection learning, as the solution, is a learning that combines peer analysis and self-reflection. The purpose of this study was to describe the implementation of Peer-Assisted Reflection learning based on student opinions in Multivariable Calculus lecture. The research design used was pre-experimental with a one-shot case study design. The data obtained from questionnaire responses were analyzed by using descriptive statistics. The result of this study shows that the Peer-Assisted Reflection learning help students carry out activities: reflecting the result of their own work, commenting on the friend's work, and increasing understanding of the material after revising their work. On contrary, the PeerAssisted Reflection learning has not been able to carry out the following activities: determining concepts, understanding problems in a short time, understanding the work of colleagues, and finding doubts about the correctness of the answers.
\end{abstract}

\begin{abstract}
Abstrak: Kelas yang besar dapat menjadi sumber permasalahan dalam pembelajaran Kalkulus. Pembelajaran Peer-Assisted Reflection dapat mengatasi permasalahan ini. Peer-Assisted Reflection adalah pembelajaran yang menggabungkan antara kegiatan analisis rekan dan refleksi diri. Tujuan dari penelitian ini adalah untuk mendeskripsikan pelaksanaan pembelajaran Peer-Assisted Reflection berdasarkan pendapat mahasiswa dalam perkuliahan Kalkulus Multi variabel. Desain penelitian yang digunakan adalah preexperimental dengan rancangan one shot case study. Data persepsi mahasiswa diperoleh dari angket respons. Analisis data respons mahasiswa diolah dengan menggunakan statistic deskriptif. Hasil penelitian ini menemukan bahwa pada pembelajaran Peer-Assisted Reflection, mahasiswa mampu melakukan kegiatan: merefleksi hasil kerja sendiri, mengomentari pekerjaan rekan sejawat, dan meningkatkan pemahaman materi setelah merevisi hasil kerja sendiri. Mahasiswa dalam pembelajaran Peer-Assisted Reflection belum mampu melakukan kegiatan: menentukan konsep, memahami masalah dalam waktu yang singkat, memahami hasil kerja rekan sejawat, dan menemukan keraguan terhadap kebenaran jawaban.
\end{abstract}




\section{INTRODUCTION}

$\mathrm{C}$ alculus continues to be an area of interest for research at an international level. The special issue of research evidence this in Calculus which is discussed in the journal ZDM Mathematics Education. Several studies in this journal state that the progress achieved by using Calculus theory has not had a broad impact on the actual teaching and learning of Calculus (Rasmussen, Marrongelle, \& Borba, 2014). Therefore, it is necessary to make improvements in Calculus learning to balance it with the progress of studying its concepts specifically.

Calculus learning improvement interventions often introduce technology (Zakaria \& Salleh, 2015) and/or collaborative group work (Cooper, Bailey, \& Briggs, 2015) to help students solve real-world problems. The increasing number of students in larger class sizes makes learning more difficult than before, so it directed students to study aloneor seek help from their peers. Schunk (2012) revealed that peer-assisted learning is collaborative group work that supports the quality of learning in higher education. Peerassisted learning is thought to overcome learning problems in large classes.

Reinholz (2014) suggests something new about peer-assisted learning, namely PeerAssisted Reflection (PAR). Sadler (in Reinholz, 2015) states that PAR combines the activities of peer analysis and self-reflection. The peer analysis activity is a study of the partner's work as criticism, suggestions, completion instructions, and the truth of the work. Self-reflection activity is an examination of the results of one's work before being analyzed by colleagues.

Reinholz (2015) conducted PAR on students after the calculus lecture took place. It asks students to solve open-ended problems and self-reflection outside of lectures, with peer feedback for 20 minutes at the next meeting. This study modifies the implementation of PAR learning that has been proposed by Reinholz (2015), namely problem solving and self-reflection carried out in lectures. When solving problems, students must work on them individually and self-reflection activities are carried out well. When students have difficulty identifying open-ended problems, we can immediately give students help.

The PAR learning steps are: "1) completed the PAR problem (individually), 2) selfreflected on their understanding, 3) traded with a peer and gave peer feedback during class, and 4) revised and turned in a final solution" (Reinholz, 2014:31). Implementing PAR learning in this study are: 1) students solve open-ended problems individually within 45 minutes; 2) students may reflect on their work for 15 minutes; 3) students analyze the work of colleagues for 15 minutes and provide feedback within 15 minutes; and 4) students revise their work within 15 minutes. They collect the results of the revision to be assessed by the lecturer. It included all PAR learning activities in the assignment sheet.

Currently, there is no application of PAR learning in Multivariable Calculus lectures. Previous work using PAR includes integral calculus (Reinholz, 2014), linear algebra (Calkins, Grannan, \& Siefken, 2019), and physics (based on literature surveys) (Reinholz \& Dounas-Frazer, 2016). The purpose of this study was to get information on implementing PAR learning from the perspective of students in Multivariable Calculus lectures.

\section{METHOD}

The research design used was preexperimental with a one-shot case study design. We conducted this research at one of the State Islamic Higher Education in West Sumatera. The population of this research was 
all students who were active in the Mathematics Education Study Program in the odd semester of the 2019/2020 academic year. The research sample consisted 35 students who took the Multivariable Calculus course. Response surveys were used to gather information on student perceptions of the application of PAR learning. After being validated by experts, the response questionnaire contains 20 open-ended questions. Descriptivestatistics as percentages were used to analyzethe outcomes of student replies.

\section{RESULTS AND DISCUSSION}

After engaging in seven PAR lessons, we asked students to complete a response questionnaire. Students' perceptions of PAR learning were examined in each phase.

\section{Students' perceptions of individual problem-solving activities}

We got students' perceptions of this activity through five open-ended questions. These questions relate to identifying problems, difficulties in determining concepts, how to solve problems, understanding the material, and the time provided for participating in these activities. The recapitulation of the results of students' responses in identifying problems, difficulties in determining concepts, and understanding the material, as shown in Figure1

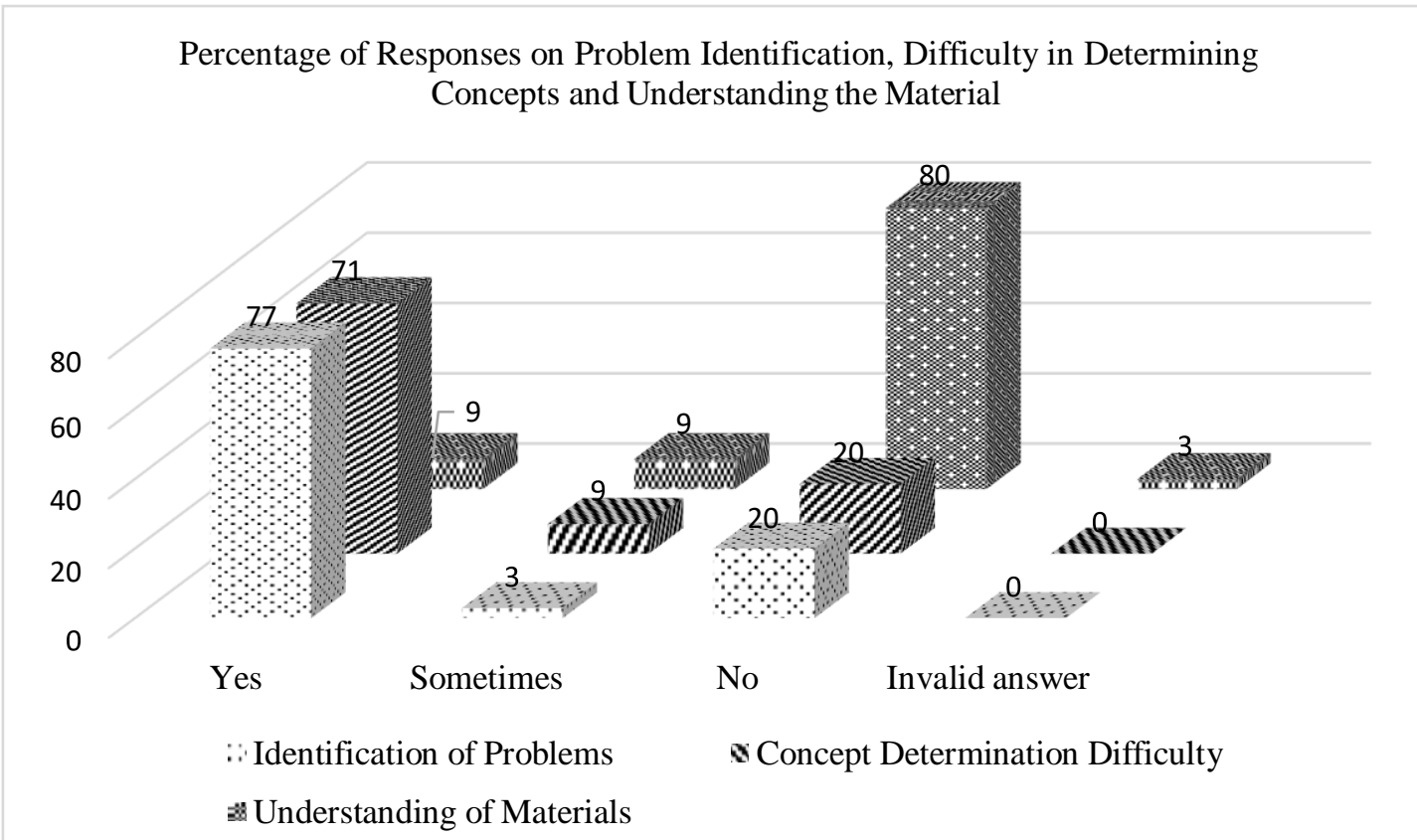

Figure 1. Students' Responses on Problem Identification, Difficulty in Determining Concepts, and Understanding of Materials

In Figure 1, we can see that students can identify calculus problems in individual assignment sheets. Some reasons put forward by students when identifying problems were that the information in the problem was very clear, detailed, and well understood. The results are contrary to research (Widodo et al., 2019) which found that most students did not identify the problem because they did not write about what they knew and asked about the question.

In the response to concept determination, the most common response was the difficulty in setting concepts for problem-solving on the task sheet (see Figure 1). The reasons for the difficulties include not understanding the 
questions given, not understanding the concepts related to the questions, being confused about determining the concepts, and referring to examples of questions. Ramadanti \& Pujiastuti (2020) also found that students had difficulty in determining concepts in Calculus material because of not understanding the concepts well.

The highest percentage of students' responses about understanding the material in
Figure 1 are students who do not understand the material after working alone in solving problems. They revealed several reasons as explained earlier, namely related to problems that were difficult to understand, the material provided was too complicated, and needed material explanations from the lecturer. We show a summary of the results on how to solve the problem in Figure 2.

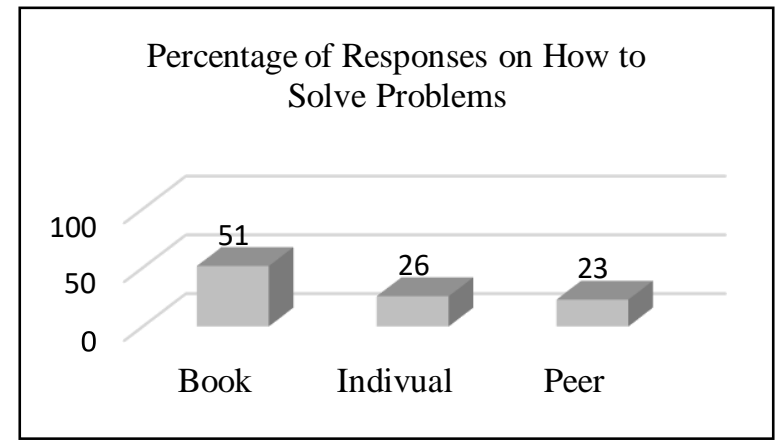

Figure 2. Students' Responses on How to Solve Problems

In Figure 2, students' responses by following the textbook are higher than by using their method. In addition, we also found responses that were inconsistent with the first step of PAR learning. When students solve problems, they do not work individually but ask in pairs, work in pairs, or copy solutions in pairs. These responses contributed to the way they solved the problems in the worksheets. A summary of the results regarding the availability of time for solving problems is shown in Figure 3.

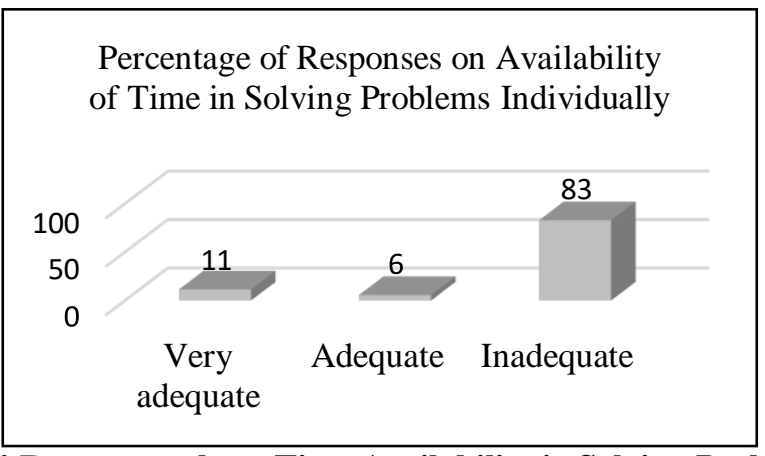

Figure 3. Students' Responses about Time Availability in Solving Problems Individually

The Figure 3 shows that 83 percent of students consider the time allotted to solve problems on the assignment sheet is insufficient. This is due to the problems presented, including high cognitive skills. students had never solved a problem like this before, and they had a hard time figuring out what concept to use. Correct identification of problems is required in solving problems, as evidenced by the presentation of the results of student responses to the implementation of the first step of PAR learning. This indicates that students can understand the first step of problem-solving. If students are not able to 
understand the problem well, they cannot proceed to the next stage of problem-solving (Widodo, 2015; Widodo et al., 2019). The accuracy of determining the concept as part of planning activities and developing settlement strategies is related to the results of students' perceptions of identifying problems. A person who has difficulty in interpreting the problem can cause him not know about planning and developing a resolution strategy (Tambychik \& Meerah, 2010). Students' ability to determine the concept has been affected by a lack of understanding of the material and time limits.

\section{Students' perceptions of reflecting on their work based on their understanding}

Students' perceptions of reflecting on their work in PAR learning were gathered using open-ended questions about theactivities they engaged in when reflecting on their work and the amount of time they were provided to do so. When students reflect, they look at things like problem-solving strategies, calculations, and graphs or drawings. Figure 4 shows students' responses to the reflection on problem-solving strategies, calculations, and graphs.

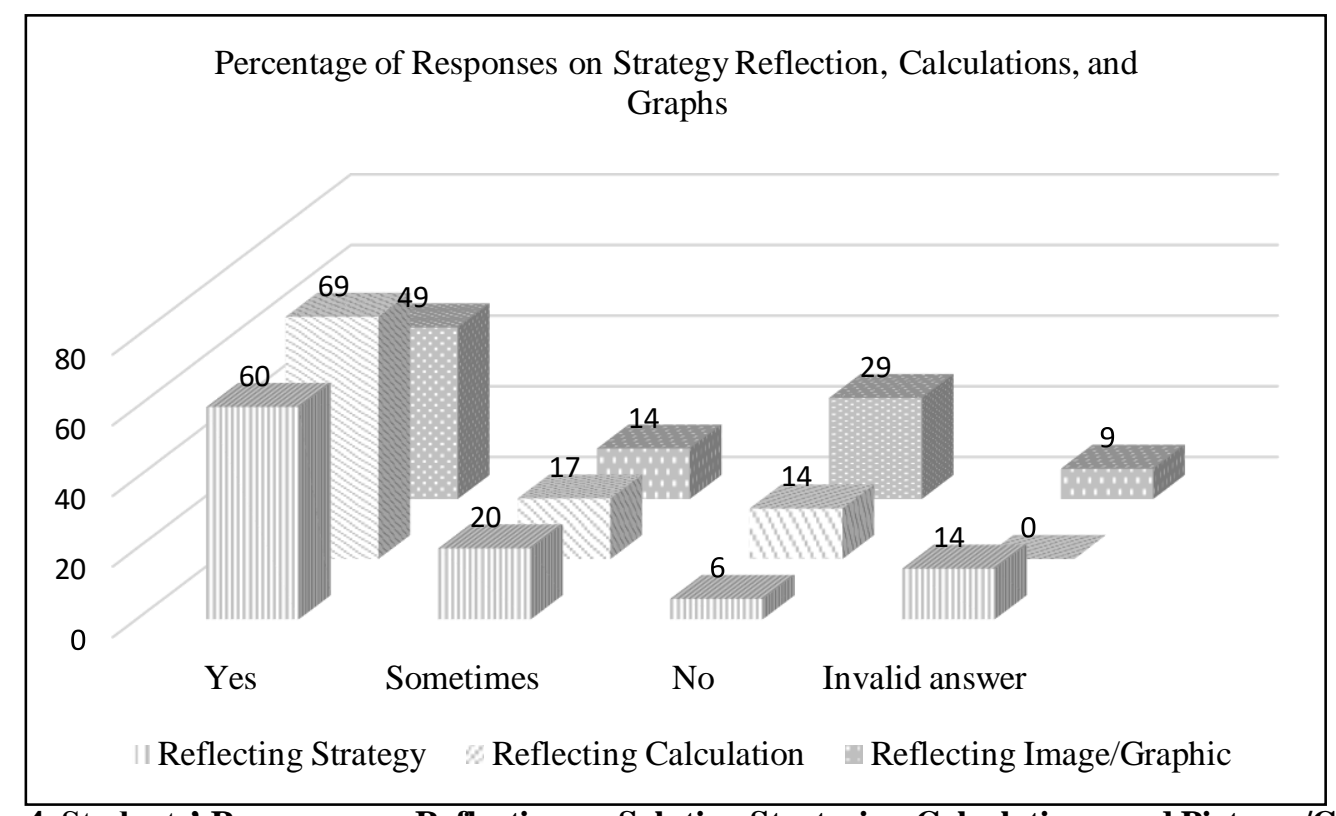

Figure 4. Students' Responses on Reflection on Solution Strategies, Calculations, and Pictures/Graphs

Figure 4 shows the findings of student responses, indicating demonstrate that students generally reflect on problem-solving strategies, calculations, and pictures/graphs. Students who did not reflect mentioned a variety of reasons, including a lack of knowledge about the truth of the chosen strategy, a lack of understanding of the material, a lack of time, doubts about the completion of the task, copying a partner's work, a lack of understanding of the graph, and a lack of caution when making graphs. 


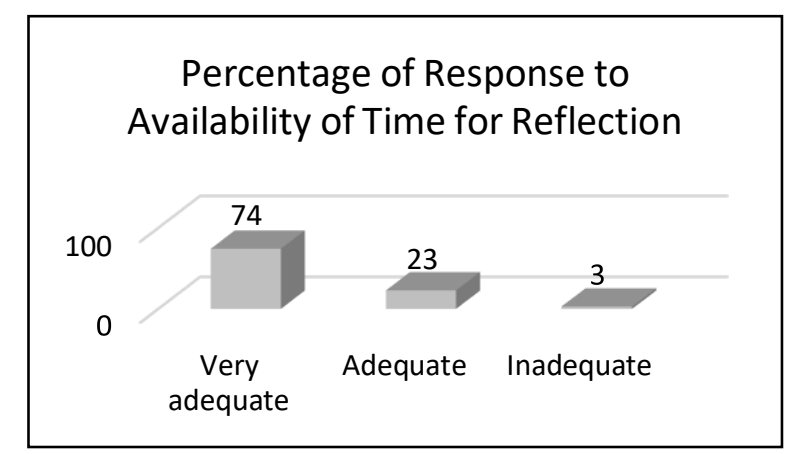

Figure 5. Students' Responses on Availability of Time to Reflect on Work Results

Figure 5 shows students' responses to determine whether the time limit was adequate. The time provided for reflecting on their work, based on students' perceptions in Figure 5, is sufficient. For students who stated that they were not adequate, they had difficulty understanding the graphs so that they needed additional time. The second step of PAR learning has been completed successfully, based on the above display of perception results. Students said that they have participated in reflection activities in general. Reinholz (2014) claims that PAR learning can improve students' reflection activities in Calculus lectures, which backs up the findings of this study.

Problem-solving activities that include reflection have a substantial role. Wheatley (1992) claims that it is not enough for students to just complete a task to solve an issue; they must also reflect on their actions. Questioning every procedure that has been carried out throughout individual problem-solving can be used to reflect on work results. Calkins et al.
(2019) reveal a way of reflecting on work results by using metacognitive questions.

Students' perceptions of the activity of exchanging the work with peers and providing feedback

Students were asked to answer seven questions to obtain information on their perceptions on the activity of exchanging work and providing feedback. The questions contain about the things to do when giving feedback, the difficulties, understanding ofthe material, and the time provided. Figure 6 summarizes the results of student responsesto feedback activities and material understanding.

Figure 6 shows that students have generally commented on their partners' work. This indicates that the students has communicated with his partner by written communication. This result is in line with Calkins et al.'s (2019) findings, which showed that PAR learning enhances communication skills. 


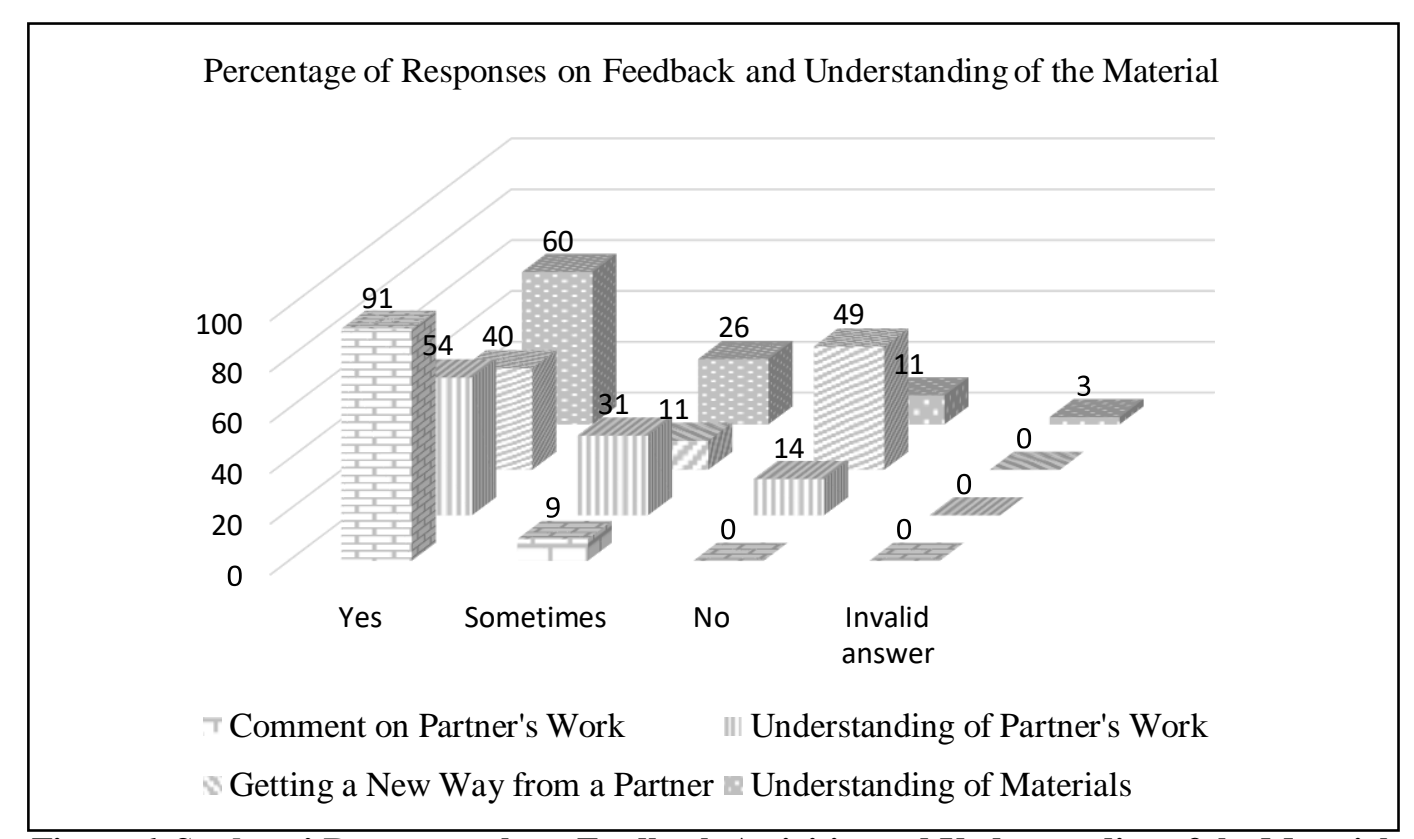

Figure 6. Students' Responses about Feedback Activities and Understanding of the Material

Students' comments can take the form of the process that must be followed (Figure 7a), orders (Figure $7 b$ ), and the pair's correct answer (Figure 7c) (Figure 7c). Most of the students already understand their partner's work. For students who respond sometimes understand that they have difficulty when their partner has not finished their work or the results of their partner's work are not clear. Meanwhile, students who did not understand stated that there were differences in solutions.
Most students do not find new ways to solve problems on the worksheets in PAR learning (see Figure 6) because they have the same answers. After giving feedback to the partner's work, the students understanding of calculus material increased. These results can be seen in Figure 6. Some students statedthat their partner explained back about their work. There are even those who repeat the study of their partner's work.

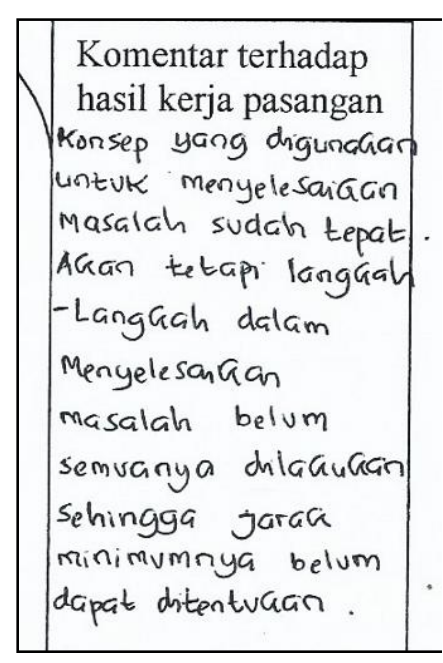

a

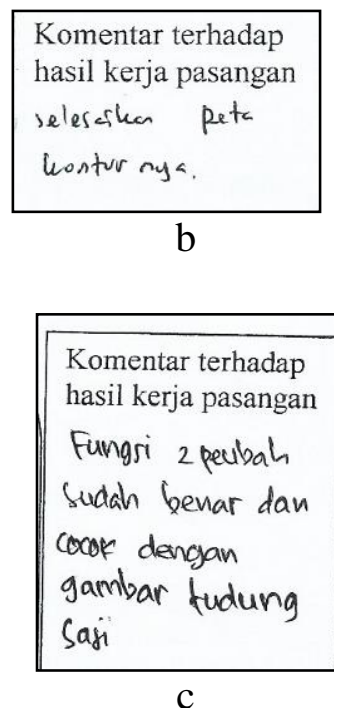

C

Figure 7. Example of Comments on the Work of Couples on the Worksheet 
While asked about the problems they face when reviewing their partner's work, the most prevalent explanation given is a lack of understanding in establishing the correct answer due to the use of different concepts. The students' second problem was that the pair solution was difficult to understand because of the various answers. The third difficulty relates to the partner not filling out the task sheet or not completing the work. The fourth difficulty is in the form of clarity and neatness of writing. Figure 8 shows a summary of student responses to difficulties with double-checking their partners' work

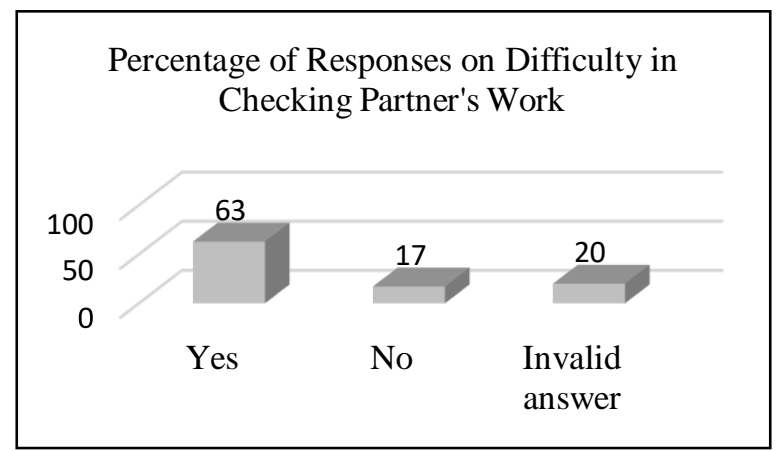

Figure 8. Students' Responses about Difficulties in Checking Partner's Work

The time provided for commenting and discussing the results of work with partners on PAR learning is sufficient. All students think about the adequacy of time to commenton the work of their partner. About $80 \%$ of students stated that they had sufficient timeto discuss with their partners.

It may be concluded that the feedback activity was successfully executed based on students' perceptions of the third step of PAR learning. Task processing and self-regulation include student feedback (Hattie \& Timperley, 2007). Reinholz (2017) asserts that both categories focus on how students interact with assignments, choose strategies, reflect on strategies and understand what has been done. The disadvantage of this activity is that students have not found several openended problem-solving strategies. Students are morelikely to have the same solution as their partners.

Students' understanding improved marginally after completing the third step, compared with the previous step, because they had to explain their work to each other to arrive at a correct answer. Nicol et al. (2014) stated that peer review can improve conceptual understanding. In addition, Calkins et al. (2019) argues that peer learning offers students' ability to communicate their ideas around content, as well as the ability to defend or test their understanding when challenged.

\section{Students' perceptions of the activity of revising and changing the results of the work into the final solution}

In the last step of PAR learning, students are required to revise their work. To learn about their opinions on the activity's implementation, students answered three questions on the difficulty, understanding of the material, and availability of time to complete these tasks. The dominant difficulty for students when revising their work is determining the correct answer. Because they found different settlement strategies, they felt less sure of the correctness of the steps and the results obtained. Other difficulties experienced by students are: 1) not understanding the work that is being revised; 2) unable to complete the work that needs to be revised; 3) do not understand the concept, especially the material for drawing graphics; 
4) does not understand the partner's comments and suggestions; and 5) the results of the partner's work are different from the results of their own work.
Students' understanding of Calculus material after revising their work is increasing. Students' responses are summarized in Figure 9.

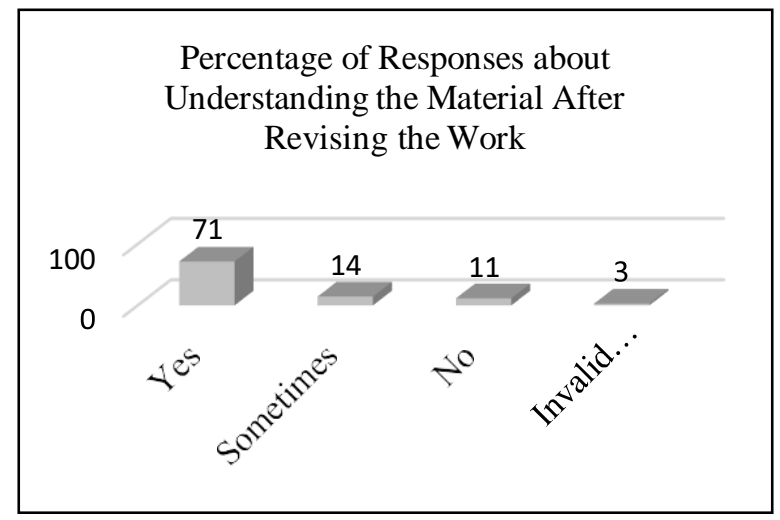

Figure 9. Students' Responses about Understanding the Material after Revising Work Results

In the previous step, $60 \%$ of students understood the material. In the last step of PAR learning, based on Figure 9, about $71 \%$ of students understood the material. This indicates that students are increasingly understanding the material after going through all the steps of PAR learning. The increase in the number of students who understand the material comes from students who sometimes understand thematerial in the third step of PAR learning. Meanwhile, the percentage of students who did not understand the material and abstainedwas still the same as the third step of PAR learning.

In general, students agreed that the time allowed for revising the work results was adequate. Figure 10 shows these findings. It can be seen in Figure 10 that there are still students who state that the time given to revise their work is not sufficient. Some students respond that sometimes the time isadequate. In general, students think that the time to revise is enough.

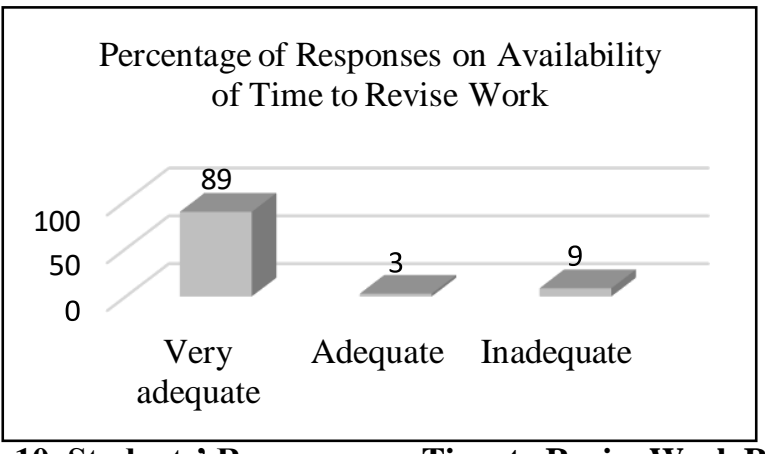

Figure 10. Students' Responses on Time to Revise Work Results

Overall, students' perception that the final part of PAR learning, revising the work, was well- executed. Reinholz (2016) discovered that when students are allowed to revise, they can benefit from the feedback provided by their partners. As a result, students make the most of the opportunity to revise their work to completely understand the material and get the highest possible scores.

In the implementation of this step, it was found that students had problems revising their work as a result of differences in answers 
with their partners, thus raising doubts about the correctness of their respective work. This obstacle arises because the tasks that students do are open-ended problems. Al-Absi (2013) states that open-ended problems can affect students' mathematical beliefs and think.

\section{CONCLUSION}

Multivariable Calculus lectures can be taught using PAR learning. Based on students' perceptions, the activities that they have done well in PAR learning include: reflecting on their work, commenting on the work of colleagues, and improving their understanding of the material after revising their work. Activities that have not been carried out well in PAR learning are: determining the concept, understanding the problem for a long time, understanding the partner's work, and doubting the correctness of the answer.

Future researchers who are interested in applying PAR learning should pay attention to the advantages and disadvantages that have been disclosed. An example of how to overcome the weaknesses of PAR learning in determining the concept is the provision of modules.

\section{REFERENCES}

Al-Absi, M. (2013). The Effect of Open-ended Tasks-as an Assessment Tool-on Fourth Graders' Mathematics Achievement, and Assessing Students' Perspectives about it. Jordan Journal of Educational Sciences (Vol. 9).

Calkins, S., Grannan, S., \& Siefken, J. (2019). PRIMUS Problems, Resources, and Issues in Mathematics Undergraduate Studies Using Peer-Assisted Reflection in Math to Foster Critical Thinking and Communication Skills Using PeerAssisted Reflection in Math to Foster Critical Thinking and Communication Sk. Taylor \& Francis, 30(4), 475-499. https://doi.org/10.1080/10511970.2019. 1608608
Cooper, T. E., Bailey, B., \& Briggs, K. S. (2015). Gender differences in achievement in an inquiry-based learning precalculus course. International Electronic Journal of Mathematics Education, 10(2), 97-110. https://doi.org/10.12973/mathedu.2015. $107 \mathrm{a}$

Hattie, J., \& Timperley, H. (2007, March). The power of feedback. Review of Educational Research. https://doi.org/10.3102/0034654302984 87

Nicol, D., Thomson, A., \& Breslin, C. (2014). Rethinking feedback practices in higher education: a peer review perspective. Assessment and Evaluation in Higher Education, 39(1), 102-122. https://doi.org/10.1080/02602938.2013. 795518

Ramadanti, F., \& Pujiastuti, H. (2020). Analisis Kesulitan Mahasiswa Pendidikan Matematika Menyelesaikan Soal Pada Mata Kuliah Kalkulus I. Jurnal Cendekia: Jurnal Pendidikan Matematika, 4(2), 487-494. https://doi.org/10.31004/cendekia.v4i2. 248

Rasmussen, C., Marrongelle, K., \& Borba, M. C. (2014). Research on calculus: what do we know and where do we need to go? ZDM - International Journal on Mathematics Education, 46(4), 507515. https://doi.org/10.1007/s11858014-0615-x

Reinholz, D. L. (2014). Explanation and reflection in calculus learning. University of California. University of California, Barkeley.

Reinholz, D. L. (2015). Peer-Assisted Reflection: A Design-Based Intervention for Improving Success in Calculus. International Journal of Research in Undergraduate Mathematics Education, 1(2), 234-267. https://doi.org/10.1007/s40753-0150005-y 
Reinholz, D. L. (2016). The assessment cycle: a model for learning through peer assessment. Assessment and Evaluation in Higher Education, 41(2), 301-315. https://doi.org/10.1080/02602938.2015. 1008982

Reinholz, D. L. (2017). Peer conferences in calculus: the impact of systematic training. Assessment and Evaluation in Higher Education, 42(1), 1-17. https://doi.org/10.1080/02602938.2015. 1077197

Reinholz, D. L., \& Dounas-Frazer, D. R. (2016). Using Peer Feedback to Promote Reflection on Open-Ended Problems. The Physics Teacher, 54(6), 364-368. https://doi.org/10.1119/1.4961181

Schunk, D. H. (2012). Learning theories: An educational perspective. Reading (Vol. 5).

Tambychik, T., \& Meerah, T. S. M. (2010). Students's' difficulties in mathematics problem-solving: What do they say? In Procedia - Social and Behavioral Sciences (Vol. 8, pp. 142-151). https://doi.org/10.1016/j.sbspro.2010.12 .020

Wheatley, G. H. (1992). The role of reflection in mathematics learning. Educational Studies in Mathematics, 23(5), 529-541. https://doi.org/10.1007/BF00571471

Widodo, S. A. (2015). Keefektivan Team Accelerated Instruction Terhadap Kemampuan Pemecahan Masalah dan Prestasi Belajar Matematika Siswa Kelas VIII. Kreano, Jurnal Matematika Kreatif-Inovatif, 6(2), 127. https://doi.org/10.15294/kreano. v6i2.4388

Widodo, S. A., Turmudi, \& Dahlan, J. A. (2019). An error Students's in mathematical problems solves based on cognitive development. International Journal of Scientific and Technology Research, 8(7), 433-439.
Zakaria, E., \& Salleh, T. S. (2015). Using technology in learning integral calculus. Mediterranean Journal of Social Sciences, 6(5S1), 144-148. https://doi.org/ 10.5901/mjss.2015.v6n5s 1p144 